species. In fact, our lab was involved in those studies. By 2010, switchgrass had been removed from the state noxious weed list. In support of this, our research results showed that it has a very low potential to become invasive in the state.

\section{Joseph DiTomaso}

Cooperative Extension Weed Specialist

Department of Plant Sciences, UC Davis

\section{Seaweed as a source of omega-3 fatty acids}

Regarding "Food as Medicine" (July-September 2011): The authors must be aware of the sources of omega-3 fatty acids. Seaweed salad from Korea solves the problem without using fish. I consume some with my nopalitos for breakfast every morning. The public should be aware of this source of omega-3 fats.

Andrew A. Benson

Scripps Institution of Oceanography

UC San Diego
Angela Zivkovic, author of "Dietary omega-3 fatty acids aid in the modulation of inflammation and metabolic health" (July-September 2011), responds: While seaweed (wakame) is a source of omega-3 fatty acids, it contains modest amounts. According to the U.S. Department of Agriculture nutrient database, there are 186 milligrams of eicosapentaenoic acid (EPA) per 100 grams of raw seaweed. This is one-third of the amount in an equivalent portion of raw pink (wild) salmon. There is even less in dried seaweed: 87 milligrams EPA per 100 grams. An entire package of dried seaweed usually contains 100 grams of seaweed, which is typically not consumed by one person in 1 day.

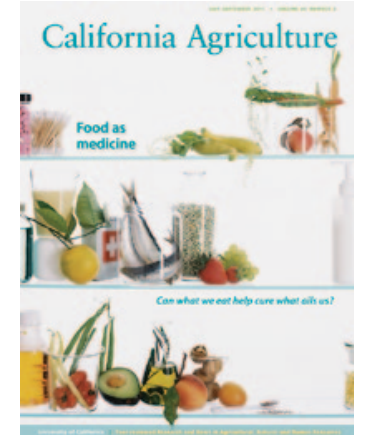

July-September 2011 California Agriculture

\title{
First phase of Hilgardia Project under way
}

7 he Hilgardia Project, launched in April 2011 to

1 bring the classic UC publication to the Web, has received $\$ 26,550$ in donations and pledges and is nearing its fundraising goal of $\$ 30,000$.

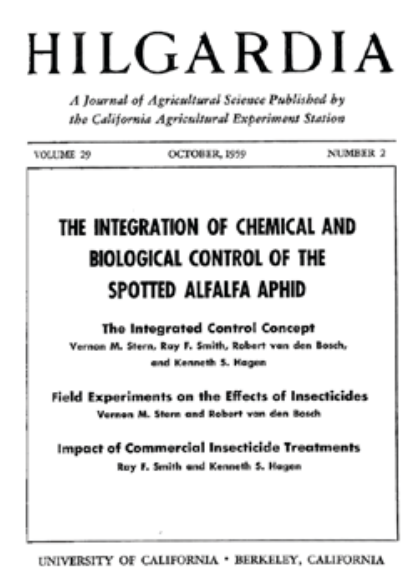
The project's first phase - preparing the Wine and Grape Collection for posting online - is under way.

For 70 years, until publication ceased in 1995, Hilgardia was the primary technical publication of UC Agriculture and Natural Resources. The archive includes classic research in agricultural, environmental and nutritional sciences, content that is still widely cited and valuable to industry and scholars.

At present, Hilgardia has virtually no online presence, and half of published issues are out of print. The rest are paperbound, subject to wear and tear. When digitized, these works will be posted on a sister site to California Agriculture journal and become freely available to scholarly and lay readers.

To make a donation or for more information, write to calag@ucdavis.edu, e-mail Deborah Golino at dagolino@ucdavis.edu or go to http://californiaagriculture.ucanr.edu/hilgardia.cfm.

The Hilgardia Project gratefully acknowledges the following donors, whose generosity has made it possible to begin scanning and posting this vital work (31,304 pages and 966 articles): 橡 PLATINUM DONORS

Anonymous gift in memory of Harry Lawton, UC Riverside, honoring his contributions to UC

Lodi Winegrape Commission, in support of the Wine and Grape Collection

Northern California Entomological Society, in support of the Entomology Collection

(\$2,500 to $\$ 4,999)$

Frank G. Zalom, UC Cooperative Extension Specialist, Integrated Pest Management

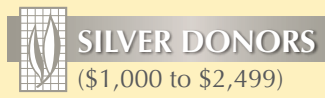

Anonymous gift in tribute to Donald Burdick, recognizing his contributions to CSU Fresno James Doyle, retired UC Davis plant breeder Paramount Farming Company

Ernest P. Peninov

Plant Sciences, Inc.

Vintage Nurseries LLC

BRONZE DONORS

(\$500 to \$999)

John Neal

\section{Friends of Hilgardia (under \$500)}

G. Stuart Pettygrove, UC Cooperative Extension Soils Specialist

- Janet White 